\title{
Danish Folkloristics: between Philology and Ethnology
}

\author{
Michèle Simonsen \\ University of Copenhagen \\ simonsen.michele@gmail.com
}

\begin{abstract}
This paper gives an overview of the most important scholars within Danish folkloristics - Svend Grundtvig, Axel Olrik, Evald Tang Kristensen, Bengt Holbek, Iørn Piø - and argues that, although most of them were originally trained in philology and mostly interested in oral literature, they were all, each in their own way, concerned with the "ecology" of folklore: i.e. its interplay with its environment. Who were the "folk" and what was "lore" for these scholars? The paper also tries to assess how Danish folkloristics deals with the contemporary shift of paradigm from folkloristics to cultural studies.
\end{abstract}

KEYWORDS

Folklore; Denmark; Ballads; Epic Laws; Svend Grundtvig; Axel Olrik

\section{RESUM}

Aquest article ofereix una visió general dels estudiosos més importants del folklore danès -Svend Grundtvig, Axel Olrik, Evald Tang Kristensen, Bengt Holbek, Iørn Piø- $i$ sosté que, encara que la majoria d'ells van ser formats originalment en filologia i sobretot es van interessar per la literatura oral, estaven tots, cadascú a la seva manera, d'acord amb l'«ecologia» del folklore: és a dir, la seva interacció amb l'entorn. Què era el "poble» (folk) i què era la «saviesa» (lore) per a aquests erudits? L'article també tracta d'avaluar com els folkloristes danesos van tractar el canvi de paradigma des dels estudis folklòrics als culturals.

PARAUles ClAU

Folklore; Dinamarca; Balades; Lleis de la narrativa; Svend Grundtvig; Axel Olrik 
Although SOME OF THE MOST FAMOUS FOLKLORISTS have been Danish (Svend Grundtvig, Axel Olrik, Evald Tang Kristensen, Bengt Holbek, etc.), Danish folkloristics had a very short and tenuous institutional life. As an independent university department, ${ }^{\mathrm{I}}$ it only existed for 30 years. It was also the smallest university department in the Faculty of Humanities. It was set up in 1967 by Lauritz Bødker, who had studied in Lund, Sweden, under Carl-Wilhelm von Sydow, but his professorship was personal so, after his retirement, the department did not have a professor, only three senior lecturers. When Michael Chesnutt and myself joined the department in I983, coming from the English and the French departments, the staff went up to five members for a while. However, two of the original members of staff had by then effectively left the field of folkloristics and turned their interest towards documentary film-making (Karsten Biering) and the history of school medicine (Birgitte Rørbye). The Department of Folkloristics was closed down in 1998, so this discipline can no longer be studied in Denmark.

Another peculiarity of Danish folkloristics - and one reason for its institutional weakness - is that the field of folk culture is split into two subjects. You could study non-material folk culture at my department, but material folk culture at the Department of Folk-Life Studies. ${ }^{2}$ The distinction between material and nonmaterial culture, strange as it may seem, has historical reasons. Folk-life research was founded by museums and for a long time trained curators of local and regional folk museums; whereas Folkemindevidenskab was conceived as a special area of literature and started out training archivists.

There is also a third institution, Dansk Folkemindesamling, the Danish Folklore Archives, founded in I904, which has always been completely separate from the two university departments. Until recently an independent institution, it is now part of the Royal Library, although it retains some of its autonomy. So the study of folkloristics in Denmark has been split into three different institutions.

\section{Between philology and ethnology}

I have entitled this paper "Danish Folkloristics: between Philology and Ethnology".

By 'philology' I mean the study of texts as artefacts, with formal and semantic characteristics, whether these artefacts be verbal, gestural or conceptual: i.e. beliefs and customs as well as ballads or legends. And by 'ethnology', I mean the "ecology" of these artefacts, in the original sense of the word 'ecology': that is,

I. "Institut for Folkemindevidenskab", later renamed "Institut for Folkloristik" in I987: I967-1998.

2. "Institut for Europæisk Folkelivsforskning”, later renamed “Europæisk Ehnologi”. 
their relationship with their environment. An overview of the history of Danish folkloristics shows that most scholars have come from philology in the narrow sense of the word, and their main research interest has been oral literature. Even so I would claim that the impact they have had on European folkloristics is due to the fact that they have had, long before their time, an approach to their subject that was ethnological.

\subsection{Svend Grundtvig}

Svend Grundtvig (I824-I883) was the son of N.F.S. Grundtvig (I783-I872), poet, clergyman and social reformer, and one of the most influential intellectual leaders of the period. He was partly educated in Danish, English and Icelandic philology by his father, who infused him with the ideas of Herder, but in a more patriotic form of national romanticism. At the age of I8, Svend Grundtvig published an annotated book of English and Scottish ballads, translated into Danish (Grundtvig I842) He is mostly famous for his monumental of Danish Ballads, Danmarks gamle Folkeviser $(D g F)$, which he started in I853 but which it took IO2 years for his successors to complete.

Danmarks gamle Folkeviser is a huge scholarly edition of ballad texts, from $16^{\text {th }}$ century manuscripts to contemporary items from the oral tradition, with learned commentaries that disentangle the history of their many versions and compare them with Scandinavian and European parallels. Grundtvig's main claim to fame is to have formulated and put into practice principles for the edition of popular ballads, inspired by the Scottish antiquarian Motherwell (I797-I835) and which were quite revolutionary for the time (Grundtvig I847). In order to edit Danmarks gamle Folkeviser, Svend Grundtvig published an appeal to "all men and women of Denmark" and "with warm feelings for their native land and for its spiritual property" to contribute to this national enterprise by sending in the Danish ballads they knew or could collect from living oral tradition. Using as sources old manuscripts, broadsides and the oral tradition, Grundtvig planned to publish all known versions of every ballad, even if they differed only slightly, and to publish them unaltered. These principles are now common practice among modern folklorists and ballad scholars, but at the time they were almost unheard of and raised violent criticism from Danish philologists. The controversy was known as "the Ballad Feud", and opposition to the publication was led by Christian Molbech, who claimed that such an edition would be "a wild aggregate of raw texts" (Petersen 1905: 77), and the historian Johannes Steenstrup, who disparagingly wrote tat "Svend Grundtvig has a strong predilection for observing the changes which the ballads have undergone during the previous centuries and right up to the present time, though this must be of insignificant interest as compared with the great and important problem of finding the oldest genuine form" (Steenstrup I89I: I-2). But Grundtvig claimed that there was no such "single original" ballad. He viewed ballads and ballad tradition as living organisms, and each variant had a value in itself that, if not aesthetic, was at least historical, as a segment in the chain of tradition. Fortunately, Grundtvig's principles prevailed, and were a direct inspiration for F. J. Child (I825-I896) when he published his monumental edition of English and Scottish ballads. 
Admittedly, Grundtvig only applied these principles to the scholarly editions of ballads. In his popular editions, he returned to the time-honoured practice of his enemies and reconstructed what he thought was the "best" version of a ballad. He also had a strong national romantic agenda. His views on ballads as the folk poetry of the North are very much the product of his time: the ballad was necessarily created by the spiritual genius of the Northern people, in the "folk poetic era" following the era of "folk myths" in the Middle Ages. "Folk poetry is not a genre that is continually created, nor something which may be repeated from time to time. It has its own historical place in the history of the people" (Grundtvig I847: 25). And some of his scholarly comments on individual ballads have been refuted since, especially those concerning chronology, for he stated that the heroic ballads were the oldest. (He did not talk of ballad types, only of ballads, but he operated with the concept of type, since he grouped together versions under a title and gave them a number). But his fight for "publishing all there is, as it is" shows an amazing sensitivity to the life of ballads as living organisms and to the very nature of folklore, its ability to generate variants, all worthy in their own right. Svend Grundtvig studied ballads as traditional forms, and understood that the basic characteristic of tradition is the interplay between stability and variation. His view on ballads as living organisms influenced his student Axel Olrik, and was of vital importance for the Finnish school.

\subsection{Axel Olrik}

Axel Olrik (I864-I9I7), who continued Grundtvig's work with the edition of $D g F$, is mostly known abroad for his "epic laws of folk narrative". Although he died at the age of 52, his scholarly interests were far-reaching and his production immense. He was interested in and wrote intensively on history and archaeology, ancient Scandinavian heroic poetry and mythology; on ballads, folk tales and also on other aspects of folklore. He also did some field work in southern Jutland - at the time part of Germany. He wrote his doctoral thesis on the sources of Saxo Grammaticus's Gesta Danorum. This chronicle of the mythical kings of Denmark, written by a royal scribe around I200, has occupied historians since the $\mathbf{I}^{\text {th }}$ century (Friis-Jensen I98I). Olrik scrutinizes the first nine books, devoted to the first mythical Danish kings and, by comparing them with both Icelandic sagas and Danish contemporary legends, concludes that they are legends, not historical sources, and must therefore be studied from a cultural-historical approach, supported by folkloristic observations.

Olrik was also a great organizer. He founded the Dansk Folkemindesamling (Danish Folklore Archives) in I904, and co-founded a periodical, Danske Studier, for literary and folkloristic debate, the international society of Folklore Fellows $(F F)$ in I907, and Danmarks Folkeminder (Denmark's Folklore), a society for the collecting of folklore in I908.

He planned a synthesis of his view on folklore, which was posthumously published by one of his students, Hans Ellekilde, (Some principles for the study of "Sagn") (Olrik I92I). His system included principles for the study of sources, a theory of transmission and, most influentially, a theory of form which he called "epic laws". Most of these "epic laws" seem obvious to a modern reader, (although some of them have been refuted) but they were quite novel at the time: 
I. Law of Beginning and Ending: There is a move from calm to excitement at the beginning and in the opposite direction at the end. There are formulas: "Once upon a time," and "They all lived happily ever after".

2. Law of Repetition: The same action is repeated to build tension, and fill the body of the narrative.

3. Law of Three: Events happen in threes. Groupings may come in threes.

4. Law of Two to a Scene: Maximum number of two in a scene at a time. Groups may not be differentiated, and are treated collectively as one of the pair. If extras appear in a scene, they are normally silent.

5. Law of Contrast: Polarization between characters: good/evil, young/old, beautiful/ugly.

6. Law of Twins: Two characters appear in the same role.

7. Law of the Importance of Final Position: The character to act last evokes the most sympathy. Often turns out to be the hero(ine) (younger brother and sister; the third knight trying his luck, etc.).

8. Law of the Single Strand: Normally only one plotline. No extraneous details. No flashback.

9. Law of Use of Tableaux Scenes: These are 'sculptured situations'. The dominant images that characterize major events of the tale.

Io. Law of Logic of the Sage: Events/characters cannot be measured by the logic of our world. There is magic. Need for suspension of disbelief.

II. Law of Unity of Plot: Events occur in a logical sequence and go towards the main plot.

I2. Law of the Concentration on a Leading Character: Focus on one protagonist. Even where there are two heroes, one emerges in the end.

It is important to remember that Olrik's epic laws are not just formal characteristics. For him, they had an impact upon the assessment of historical sources. Olrik stated that historical sources often contain peculiarities that can only be understood if the influence that epic laws have had on their form is recognised. Epic laws are the filter that shapes the sources, and this must be taken into account when their source value is assessed. For Olrik, epic laws were only one part of a comprehensive system for the study of folklore.

\subsection{Evald Tang Kristensen}

Evald Tang Kristensen (I843-I929) is probably the most prolific and greatest collector of folklore from his period in Western Europe. Unlike Grundtvig and Olrik, who came from the high bourgeoisie, Tang Kristensen was of humble origin, the son of a school teacher and a teacher himself, until a government grant allowed him to go on collecting trips and later on to give up teaching altogether. At the age of I8 he started collecting ballads from an old woman, the famous Sidsel Jensdatter (who has the same mythical status in Denmark as Dorothea Wick, the "Märchenfrau" of the Grimm brothers), but soon extended his collecting to all aspects of folklore. He felt that he was on the same wave length as the peasants of Jutland, the poor people of the moors, whom he collected from, 
and often stayed the night in their homes. He collected incessantly, consulted his field notes to make various fair copies, published almost 80 books, and founded a journal of folklore and, together with Henning Frederik Feilberg and Axel Olrik, the society for the collection of folklore. Although he claims to be a collector, and not a theoretician, he had strong views about the nature of folklore, which he expressed explicitly or implicitly in all his books, letters and lectures. Moreover, although he translated them from the dialect to standard Danish for publication, he published the results in a style that was amazingly close to the oral enunciation for his time. His many field notes are preserved at the Danish Folklore Archives, together with the numerous fair copies, so the whole process from field notes to publication can be followed. His concern for and interest in his informants was amazing for the time. His memoirs give a minute account of all the poor people he visited and what he collected from each of them, and together with the photographer Peter Olsen he made a trip to take pictures of some of his best informants, which resulted in a beautiful publication, Gamle Kildevoeld. Nogle billeder af vissangere og aeventyrfortoellere.

\subsection{Bengt Holbek}

Closer to our own time, Bengt Holbek, working with folk tales, and his fellow student Iørn Piø, working with Danish ballads, treated traditional folk literature with what I call an ethnological approach, although their material was so old they could not make use of modern performance theories. But they both made the most of whatever contextual information they could dig up.

In his monumental thesis on Danish wonder tales, Interpretation of Fairy Tales. Danish Folklore in a European Perspective, Bengt Holbek studies the genre of fairy tales as they were collected by Evald Tang Kristensen from the Danish peasantry between I857 and I923. He sets them in the context of the social conditions, ways of life and mentality of these people, the story-tellers and their audience; and analyses the process by which the concerns of the folk were turned into poetic narratives, through three narrative patterns, involving three basic oppositions between adult and young, low and high, and male and female; and through a set of six tools to produce symbols specific to the genre:

- Split: conflicting aspects of a character are distributed among different figures in the tale.

- Particularization: aspects of people, phenomena and events appear as independent symbolic elements.

- Projection: feelings and reactions in the protagonist's mind are presented as phenomena occurring in the surrounding world.

- Externalization: inner qualities are expressed by attributes or through actions.

- Hyperbole: intensity of feeling is expressed by exaggeration of the phenomena eliciting the feeling.

- Quantification: quality is often expressed as quantity.

He studied in minute detail each of Tang Kristensen's hundreds of informants, their biography, their individual repertoire, and their own style of narrating. 
To my mind, this is as close as one can get to an ethnological approach to the recorded, written texts of $19^{\text {th }}$ century fairy tales.

\subsection{Iørn Piø}

Iørn Piø, who was one of the scholars to complete the edition of $D g F$, wrote his doctoral thesis on Danish ballads. He challenges the dogma, favoured until then by literature scholars, that the Danish ballads, which are found in noble men and women's manuscripts from the $5^{\text {th }}$ century onwards as well as recorded among peasants in the $19^{\text {th }}$ century, are medieval aristocratic ballads that have ended up as popular ballads in the modern tradition. Piø thought he could isolate another milieu for the birth and life of ballads, the broadside ballads of the market place. He claims that a great many so-called Danish medieval ballads were created later than assumed until then, in the style of the market-place ballad, thus making the history of Danish balladry more like that of other European traditions. This fact that had been blurred until then by the extraordinary richness of noblemen's manuscripts from the $16^{\text {th }}$ century. Piø's market-place theory is not fully accepted by all ballad scholars, but what I find interesting, and very Danish, is that his research so to speak "does fieldwork in archive material". Piø is interested in the tradition of the ballads in the real sense of the word: their creation, distribution and uses. In short, their social life.

\section{What is folklore?}

The two main questions and controversies throughout the history of folklore studies have been: I. Who are the folk? And 2. What is lore? What stand have Danish folklorists taken on these questions, either explicitly or implicitly?

\subsection{Who are the folk?}

Svend Grundtvig, like his father N.F.S. Grundtvig, who was part of the national romantic movement, viewed the "folk" as a nation in the Herderian sense of the word: a group of people sharing the same history, language, values and character, distinct from all other folks. Folk literature and folk culture expressed the distinctive soul of that folk. Folk was understood as a homogenous whole, without any social, gender or occupational distinctions.

For Evald Tang Kristensen, however, the folk were the common people (in Danish: almue), whose mentality and ways of life he partly shared and highly valued. In practice, he regarded the common people as being the peasants, the poor peasants of the moors of Jutland. He collected very little from fishermen or sailors, and almost nothing among town people.

For Bengt Holbek, the folk were those in the lower stratas of society, the underdogs, to whom he dedicated an article: "Games of the Powerless". "In times when the vast majority of the peasant population had no prospect of bettering its conditions, hopes and ideals could not be expressed in direct action. Instead, they had to be expressed in poetry, games, jokes, and magical practices". (Holbek I987: 602). 
Personally, like most modern folklorists in Western Europe, I fully endorse Alan Dundes' controversial definition of folk as "any group of people who share at least one common feature." At any time. But I do not think that everything they produce is folklore!

This leads me to the second question.

\subsection{What is lore?}

Svend Grundtvig's answer to this question is easy to find. In I865, Grundtvig launched another national campaign for collecting folkeminder (folk traditions.) He hoped to build a "museum" of all Danish popular antiquities. By this he did not mean a museum in the modern sense of the word - i.e. a building containing artefacts - but an archive. This "museum" was to comprise six "rooms" (read: six sections), containing:

I. The ballads of Denmark.

2. The folktales of Denmark.

3. The legends of Denmark, in old and new recordings.

4. Life in Denmark, "containing all the information from the past and present which it has been possible to collect about people's ways and customs. Included should be all games, both singing games and others, riddles, rhymes (nursery rhymes, pastoral rhymes, place rhymes, etc.) and strings of words used on various occasions by grown-ups or children".

5. The popular beliefs of Denmark.

6. The proverbs and sayings of Denmark.

As you can see, four of these six "rooms" concern folk literature. One concerns beliefs, while the last one, Life in Denmark, is enormous but very imprecise. It may include "customs", but Grundtvig only gives as examples games, and rhymes (i.e. oral literature again). He had a conception of folklore which to a modern mind is both very narrow and very object fixed, defined by limited, clear-cut genres. Yet, when in I863 Grundtvig was appointed professor of Nordic Philology at the University of Copenhagen, he gave an inaugural lecture in which he defined "Nordic Philology" in the following terms: "It is the branch of scholarship dealing with the spiritual life of the Nordic people in all ages and in all its manifestations, the way the spirit of this people has revealed itself and still reveals itself both in the language itself - the word, logos, the immediate expression of the spirit - and in the people's belief and poetry, in its customs, and in its whole life" (Manuscript, Dansk Folkemindesamling [DFS I83]).

We can conclude that, as a philologist, his view of the field was much wider than that of modern philology; whereas as a folklorist, his view of the field was much narrower than that of modern folkloristics.

E.T. Kristensen was a contemporary of Grundtvig, with whom he had an uneasy collaboration. His view of folkeminder, popular antiquities, was much wider, both in his practice as a collector and as an editor. The many books he published himself (about 8o) contain collections of folktales, of children's games and rhymes, jocular songs (which Grundtvig certainly did not include in $D g F$ !), a seven-volume collection of folk legends, and a four-volume collection of "folk life 
description of the people of Jutland", Gamle folks fortoellinger om Det jyske Almueliv (Kristensen [I89I-I905], I987). In this study, the enormous amount of material is organised in the following chapters:

I. About agriculture in the past.

2. About the time of serfage.

3. Houses and indoor life.

4. Social gatherings, feasts and holidays.

5. Outdoor life.

6. Our ancestors' mentality and spiritual life.

It seems that Tang Kristensen regarded as lore all aspects of cultural life that were (a) specific to the poor peasants and (b) traditional. In this regard, his view of lore is quite in line with that of folklorists of the time elsewhere in Europe. The difference, however, is that he did not share their devolutionary bias, and valued the lore of the peasants as worthy in itself, and not just as remnants of a hypothetical past.

Bengt Holbek, too, was primarily interested in folk literature. But his interest in people, and especially in the underdog, led him to shift from philology, his undergraduate subject, to folkloristics, his postgraduate subject. What really interested him most was the folk behind the lore, what folk literature meant to the people, the audience as well as the story-tellers.

For Michael Chesnutt, 'lore' is unofficial culture. "The only general definition that makes sense to me is one that contrasts cultural traits promulgated by the political and spiritual institutions of a society with those that live a life independent of formal government or instruction. Religious folklore is not in the catechism, calendar customs are not taught at agricultural colleges, and the folk tale and folksong do not owe their existence to the national literature curriculum" (Chesnutt I998: 2).

I have only had time to present very briefly a few of the best known folklorists in Denmark. They have focussed mostly on oral literature. In many respects, they are very much children of their time. But as I hope to have shown, in some respects, they have been ahead of their time because, each in their own way, they have had a more ethnological approach to their subject than was usual. For them, texts were not just artefacts: they were part of a tradition, and tradition - creation, transmission, innovation - has a life of its own. It has its own rules and involves a special type of creation.

Where does this leave us now?

From the I980s onwards, in US and Western Europe, departments of folklore have been closed or merged into departments of culture, and research concerns itself with cultural studies of all kinds. The very notion of lore seems to have been abandoned as antiquated and irrelevant. Had the department of Folklore in Copenhagen not been closed in I998, it might have followed the same trend. Certainly, there was a definite tendency along those lines among the students in the last years of the department. And at the same time, departments of literature, religion and anthropology were trying their hand at folklore although, I am sorry to say, without the necessary empirical and theoretical ballast specific to each of these disciplines, so that self-proclaimed pluridisciplinarity tended to completely 
by-pass "disciplinarity". The results have been meagre, and nothing much more has emerged from the last generation of students than average high school essays on everything between heaven and earth. A notable exception is Lene Halskov Hansen, both a ballad scholar and a ballad singer, who views ballads as a complete performance, narrative, musical and kinetic, and studies their specific poetics down to their rhythmical, metrical and articulatory details (Hansen in print).

Admittedly, the earlier folklorists' confident perception of the concept of folklore was certainly too narrow and ethnocentric, and it would be absurd to dismiss the achievements of our discipline in the last 50-60 years. But maybe we are in danger of throwing away the baby with the bath water?

It is true that poetic genres, like scientific truths and moral concepts, are ever changing and largely culture specific. We now acknowledge graffiti, tattoos and installations as "art," which would have been unthinkable fifty years ago. And the group's own view of its cultural heritage (the emic view) is often very different from that of scholars (the etic view). But all human groups operate with an aesthetic dimension ("beautiful or not?"), just as they all operate with a moral dimension ("good or not?") and a cognitive dimension ("true or not"?).

It is tempting to follow this modern trend, to dilute folklore within culture at large, and merge departments of folklore into departments of cultural studies. As a Frenchman, living in Denmark, I am highly influenced by the French school of "Ethnology of Europe" (Chiva I987). I find the research which revolves around the EHESS ${ }^{3}$ and the journal Ethnologie Française, and the Centre d'Anthropologie in Toulouse very inspiring. Many scholars do a lot of outstanding folkloristic research, although they would rather die than call themselves folklorists (in France, "folkloric" is a dirty word). But this school claims that there are no privileged areas of culture so specific as to deserve special treatment within anthropology. It claims that folklorists arbitrarily isolate certain eras of culture as either especially "symbolic" or especially "traditional". But their rejection of "lore" is built upon the work of folklorists from I50 years ago, and, it seems to me, their rejection of tradition rests upon a confusion between "inherited" and "traditional". The purpose of French ethnology is to unravel the complex network of associations that permeates all cultural expressions of a human group, no matter how small, from everyday life's simple gestures, minute sayings and humble artefacts to spectacular festivals. And of course I agree that everything in a group is connected by an underlying set of values and a specific world-view. But much as I admire the seminal and inspiring work of Daniel Fabre, Yvonne Verdier and Claudine Vassas, their position has its drawbacks. On the whole, French ethnologists are more concerned with questions of values and meanings than with questions of transmission, variation and performance. By focussing on the underlying culture, unifying the various cultural expressions of a group, they tend to be blind to the specificity of particular expressions, which are regarded as equivalent. Let me take as an example Yvonne Verdier's seminal article on the tale Little Red Riding-Hood in French tradition (Verdier I978). The article is enlightening, but it ignores the fact that the tale, imbued in Burgundian peasant culture of the $19^{\text {th }}$ century as it is, is equally determined by the constraints specific to the genre of the fairy tale (Simonsen I998: 209-2I4). And the same

3. Ecole des Hautes Etudes en Sciences Sociales 
applies to songs, proverbs, customs, etc. which are all partly dependent upon the constraints of their specific genre. Otherwise, why should the group bother with tales and legends and customs and songs, if they do not express anything else but the same culture as proverbs?

Personally, I claim that all human groups, past and present, have specific cultural manifestations that we can call "lore", the identification and study of which is the task of folkloristics. But I will qualify Dan Ben-Amos' celebrated definition of folklore as "artistic communication in small groups" (Ben-Amos I97I: 3-I5) and define folklore as "artistic and ritual traditional communication in any human group, whatever its size, whenever it functions as an interactive group, and not as a corporate group". Lore is any artistic or ritual performance that follows the constraints of traditional poetics as described by Jakobson and Bogatyrev (i.e. the acknowledgment of both pattern and variation). Folklore never occurs when a group operates as a corporate group, with one voice, but only when it operates as an interactive group, in which all members have their own voice. This is why folklore generates variation. And this is why, although the content of folklore is far too often sexist, racialist, and in many ways reactionary, the process of folklore is basically democratic. And this is why, although it is not fashionable, I am still a folklorist.

\section{References}

Bogatyrev, Piotr; Roman Jakobson (I929): “Die Folklore als eine besondere Form des Schaffens". In Verzameling van Opstellen Door Oud-Leerlingen en Bevriende Vakgenooten Opgedragen Aan Mrg. Prof. Jos. Schrijnen. Nijmegen/ Utrecht: Donum natalicium Schrijnen, p. 900-9I3.

BeN-Amos, Dan (I97I): “Towards a Definition of Folklore in Context". Journal of American Folklore no. 84: 3-I5.

ChesnutT, Michael (I998): “Who took the Folk out of Folk Narrative?". Copenhagen Folklore Notes: 2.

CHILD, Francis James (I882-I898): The English and Scottish Popular Ballads. Boston. Reprint 2002.

Chiva, Isac; Utz Jeggle (eds.) (1987): Ethnologies en miroir: La France et les pays de langue allemand. Paris: Éditions de la Maison des Sciences de l'Homme.

FriIs-Jensen, Karsten (red.) (I98I): Saxo Grammaticus. A Medieval Author. Between Norse and Latin Culture. Copenhagen.

Grundtvig, Svend, et alii (I853-I965): Danmarks gamle. Folkeviser. I-X (DgF). Photographic reprint 1966.

GRUNDTVIG, Svend (I847): Prøve på en Udgave af Danmarks gamle Folkeviser for Samfundet til den danske Litteraturs fremme ved Svend Grundtvig. Andet Oplag, med Aftryk af Planen samt nogle Tilloegsbemoerkninger. Photographic reprint in DgF I966.

- (I842): Engelske og skotske Folkeviser, med oplysende Anmoerkninger fordanskede.

- (I88I): Elveskud, dansk, svensk,norsk, foerøsk, islandsk, skotsk, vendisk, bømisk,tysk, fransk, italiensk, katalonisk, spansk, bretonsk Folkevise, i Overblik ved Svend Grundtvig. Reprint in $D g F$ II, no. 47. 
HALSKOv HANSEN, Lene (under udgivelse): “Balladesang og kædedans. To aspekter af dansk folkevisekultur". Copenhagen: Museum Tusculanum.

HolbeK, Bengt (I977): "Games of the Powerless". UNIFOL I976. Copenhagen: Institut for Folkemindevidenskab.

- (I987): Interpretation of Fairy tales- Danish Folklore in a European Perspective. Folklore Fellows' Communications 239. Helsinki: Suomalainen Tiedeakatemia.

KRISTENSEN EVALD, Tang (I89I-I905): Gamle folks fortoellinger om Det jyske Almueliv. Viborg. Reprint 1987.

- (I927) Gamle Kildevaeld. Nogle billeder af vissangere og aeventyrfortoellere. Reprint I98I.

MotherWell, William (I827): Minstrelsy, Ancient and Modern, With an Historical Introduction and Note. Glasgow.

OlRIK, Axel (I92I): Nogle Grundsaetninger for Sagnforskning. København: Det Schønbergske Forlag.

- (I908): "Episke love i Folkedigtning". Danske Studier. English translation: "Epic Laws of Folk Narrative". In Alan Dundes (ed.) (1965): The Study of Folklore. New Jersey: Englewood Cliffs.

Petersen, Carl S. (I905): "Fra Folkevisestriden". Danske Studier: 77.

Pıø, Iørn (I985): Nye veje til Folkevisen- Studier i Danmarks gamle folkeviser. Copenhagen: Gyldendal.

Simonsen, Michèle (I998): "Culture and Symbols. Some thoughts about Bengt Holbek's Interpretation of Fairy Tales”. Estudos de Litteratura Oral no. 4 (I998): 209-2I4.

STEENSTRUP, Johannes (I89I): Vore Folkeviser fra Middelalderen- Studier over deres Astetik, rette Form og Alder. Copenhagen.

VERDIER, Yvonne (I978): “Grand'mères, si vous saviez... Le petit Chaperon rouge dans la tradition orale". Cahiers de littérature orale no. 4 (I978): I7-55. 